\title{
Ekstrem dan Melampau dalam Pengistilahan al-Qur'an dan Hadith: Analisis Terhadap Pemahaman daripada Teks
}

\author{
Khadher Ahmad \\ Universiti Malaya, khadher82@um.edu.my \\ Mustaffa Abdullah \\ Universiti Malaya, mustaffa@um.edu.my \\ Mohd Yakub@Zulkifli Mohd Yusoff \\ Universiti Malaya, zulkifliy@um.edu.my \\ Sedek Ariffin \\ Universiti Malaya, sedek2001@um.edu.my
}

\begin{abstract}
Abstrak
Ekstrem dan melampau adalah merujuk kepada perilaku atau tindakan luar daripada kebiasaan. Dalam pengistilahan al-Quran dan hadith, terdapat beberapa istilah yang boleh dikaitkan dengan maksud ekstrem atau melampau. Justeru, artikel ini bertujuan untuk mengenalpasti istilahistilah dalam pemakaian teks al-Quran dan al-hadith lalu dikeluarkan pemahaman dan skop penggunaannya dalam teks. Analisis sepenuhnya menggunakan pendekatan induktif dan deduktif supaya dapat dikenalpasti dan dijelaskan maksud keseluruhan pengistilahan tersebut. Hasil kajian mendapati bahawa istilah dalam pemakaian al-Quran yang merujuk kepada maksud ekstrem atau melampau adalah $\mathrm{Ta}$ 'lu (ghuluw), Ta 'taddu (melampaui batas) dan Tatghaw (melampaui batas). Manakala dalam hadith pula menggunakan istilah Tanatț' (sikap ekstrem), Tashaddud (memberat-berat), Takalluf (memaksa-maksa diri) dan I'tida ${ }^{\prime}$ (melampaui ketentuan syariat). Keseluruhan istilah dalam al-Quran dan hadith tersebut adalah merujuk kepada beberapa bentuk sikap dan tindakan ekstrem atau melampau iaitu melampau dalam aspek ibadah dan pelaksanaannya (seperti solat, puasa dan berdoa), melampau dalam aspek muamalah (seperti aspek halal dan haram berkaitan makanan dan minuman, ikatan perjanjian dan sebagainya), melampau dalam aspek akidah dan juga melampau dalam aspek dosa dan pahala.
\end{abstract}

Kata kunci: ekstrem, ekstremis, fanatik, taasub, ideologi, masyarakat Islam, pelampau, Malaysia

\section{Extreme and Fanatic in the Terms of al-Quran and Hadith: Analysis of Understanding from Text}

\section{Abstract}

Extreme or fanatic are to refer to behaviors or actions beyond the habit. In terms of the al-Quran and hadith, there are several terms that can be attributed to extreme or fanatic purposes. Hence, this article aims to 
identify the terms use in the texts of the Quran and the hadith while release the understanding and scope of its use in the text. The analysis uses inductive and deductive approaches to identify and explain the overall meaning of the termination. The study found that the terms in the application of the Quran which refers to extreme or fanatic are Ta'lu (Ghuluw), Ta'taddu (Transcending Limit) and Tatghaw (Transcended Limit). While in the hadith the terms uses are Tanattu' (Extreme Attitude), Tashaddud (Member-weighted), Takalluf (Forced Self-Force) and I'tidā' (Surpassing the Rules of Sharia). The whole term in the Quran and the hadith refers to some form of extremism or extreme attitudes or actions that are extreme in the aspect of worship and its implementation (such as prayer, fasting and praying), extreme in the aspects of muamalah (such as halal and haram aspects related to food and drink, covenant ties, etc.), extreme in the aspect of the creed and extreme in the aspect of sin and reward.

Keywords: extreme, extremist, fanatic, obsessed, ideology, Islamic community, extremes, Malaysia

\section{Pendahuluan}

Istilah ekstrem atau merujuk kepada maksud melampau adalah merujuk kepada sikap berlebihan dalam mempertahankan kepercayaan dan tindakan yang dilakukan. Sikap ini menunjukkan kepada sikap seseorang yang tidak terbuka untuk menerima pandangan orang lain dan tidak pula merasakan bahawa segala tindakan yang dilakukan itu melampaui batasan atau bercanggah dengan tuntutan asalnya. Keseluruhannya adalah berasaskan kepada mempertahankan apa yang dipercayai. Dalam pada itu juga, terdapat beberapa istilah lain yang boleh dianggap atau diletakkan dalam mewakili sikap ekstrem. Antaranya adalah fanatik, pelampau, taasub, berlebih-lebih atau melampaui batas dan sebagainya lain.

Dalam al-Quran, sikap ekstrem atau melampau ini disebutkan dengan istilah ghuluw seperti mana dalam firman Allah SWT pada surah al-Mā'idah ayat 77:

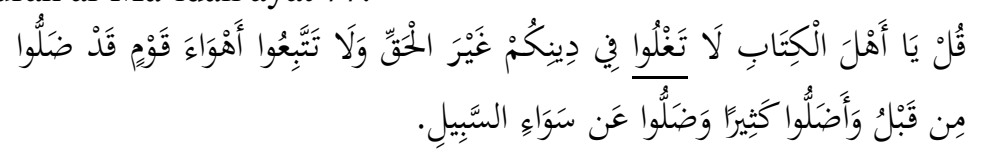

Terjemahan: Katakanlah: "Wahai Ahli Kitab! Janganlah kamu melampau dalam agama kamu secara yang tidak benar, dan janganlah kamu menurut hawa nafsu suatu kaum yang 
telah sesat sebelum ini dan telah menyesatkan banyak manusia, dan juga (sekarang) mereka telah tersesat (jauh) dari jalan yang betul."

Perkataan ghuluw tersebut dimaksudkan sebagai melampaulampau atau bersikap ekstrem secara umumnya. Bahkan sikap tersebut juga diistilahkan dengan perkataan lain, iaitu al-tanațtu“ dan al-tashdīd. ${ }^{1} \mathrm{Al}-\mathrm{Q} a r+̣ \bar{a} w \overline{1}$ menyatakan bahawa sikap taasub dan fanatik kepada pendapat sendiri mahupun guru dan kumpulan masing-masing adalah salah satu daripada gejala melampaulampau. Ia menggambarkan kebekuan fahaman seseorang yang tidak boleh melihat maslahah umum. ${ }^{2}$ Ia juga menggambarkan seseorang yang tidak berkemampuan membuka perbincangan untuk membandingkan pendapatnya dengan pendapat pihak-pihak lain bagi mengambil pendapat yang lebih kuat dalil dan alasannya. $^{3}$

Justeru, daripada sikap ini timbullah individu-individu yang terlalu bersikap fanatik atau ekstrem sehingga melahirkan golongan atau kumpulan yang mendukung ideologi masingmasing dan mempertahankannya atas dasar sikap demikian. Jadi, bagi memahami dengan lebih jelas tentang sikap melampau atau ekstremis ini, perlu kepada huraian dan rujukan dalam perbahasan terhadap teks al-Quran dan hadith Nabi SAW. Oleh itu, artikel ini akan berusaha untuk mengemukakan perbincangan berasaskan kepada rujukan terhadap teks al-Quran dan hadith serta perbahasan ulama mengenai ekstrem atau sikap ekstremis. Perbincangan secara menyeluruh terhadap isu ekstremis ini akan dapat memberikan pencerahan sebenar kepada semua pihak dalam memahami istilah serta skop pemahamannya.

\section{Ekstrem: Konsep dan Pengertian}

Dalam Kamus Dewan Edisi Keempat ekstrem adalah merujuk kepada maksud "keterlaluan", "melampau" atau "terlalu sangat". Manakala istilah "ekstremisme" pula merujuk kepada fahaman

1 Yusuf al-Qardawi, Kebangunan Islam di Antara Tentangan dan Ekstrimisme, terj. Muhammad Rivai Batubara (Kuala Lumpur: Angkatan Belia Islam Malaysia, 1984), 17.

2 Kebangunan Islam di Antara Tentangan dan Ekstrimisme, 41.

3 Mohamad Kamil Hj Ab Majid, "Fanatik dan Taksub dalam Islam: Analisis Pandangan al-Qardawi," Jurnal Usuluddin 18 (2003), 27. 
atau sikap. Contoh ayat, ekstremisme agama bukan lagi merupakan ancaman terbesar di Malaysia. ${ }^{4}$

Ibn Taymiyyah berpendapat bahawa ekstremisme bermaksud sesuatu yang melampaui batas dengan menambahkan kepada sesuatu sama ada dengan memuji atau mengeji, menolak lebih daripada yang berhak diterima dan sebagainya. Manakala menurut Ibn Hajar, ekstremisme ditakrifkan sebagai berlebih-lebihan dalam sesuatu dan memperketatkan dengan melewati batas ${ }^{5}$. Perkataan ekstremisme, fundamentalisme, revivalisme, Islamisme, radikalisme, ekstremis dan militan atau seumpamanya sentiasa diguna bergantian bagi sesetengah pihak. ${ }^{6}$ Yusuf al-Qaradawi memberi pengertian kepada maksud tațarruf al-Dīn (ekstremis keagamaan) adalah digunakan untuk hal-hal abstrak seperti melampaui batas tengah dalam agama, pemikiran atau perbuatan.

Kemudian, apabila merujuk kepada melampau, istilah ekstrem juga boleh membawa maksud melebihi had dan ketentuan yang sewajarnya, melanggar tatatertib ataupun berlebih-lebih. ${ }^{7}$ Ada juga yang mengaitkan ekstrem atau ekstremis dengan istilah terroris yang dimaksudkan sebagai pengganas. Hal ini dapat difahami bahawa dengan mengaitkan kepada maksud pengganas menggambarkan kepada tindakan golongan itu yang bertindak melampaui atasan yang sepatutnya sehingga ada yang membawa kepada tindakan membunuh, mengebom atau meletupkan tempat awam dan sebagainya.

Pada pandangan pengkaji, terdapat juga istilah lain yang turut dapat dikaitkan dengan sikap ekstrem iaitu taasub dan fanatik. Cumanya, kedua-dua istilah ini mempunyai ciri-ciri yang menunjukkan kepada pengkhususan maksud yang lebih khusus sesuai dengan skop atau batasan penggunaan istilah tersebut.

4 Dewan Bahasa dan Pustaka, "ekstreme", laman sesawang Pusat Rujukan Persuratan Melayu, dicapai 21 Julai 2016. http://prpm.dbp.gov.my/Search .aspx?k=ekstreme.

5 PKPIM UNISEL, "Pengertian Ekstremisme," laman sesawang PKPIM UNISEL, dicapai pada 22 November 2015, http://uniselpkpim.blogspot.my /2009/09/pengertian-ekstremisme.html?m=1.

6 Mohd Roslan Mohd Nor, Kefahaman Islam Semasa di Malaysia: Realiti dan Cabaran (Ekstremisme Rentas Agama dan Tamadun) (Selangor: Persatuan Ulama' Malaysia, 2015), 146.

7 Dewan Bahasa dan Pustaka, "ekstreme", laman sesawang Pusat Rujukan Persuratan Melayu, dicapai 21 Julai 2016. http://prpm.dbp.gov.my/Search .aspx $? \mathrm{k}=\mathrm{ekstreme.}$ 
Istilah fanatik merujuk kepada Kamus Dewan bermaksud terlalu berlebihan kepercayaannya atau keyakinannya terhadap sesuatu ajaran (termasuk politik dan lain-lain) hingga melampaui batas. Fanatik juga merujuk kepada (orang yang) keterlaluan pada sesuatu pegangan atau pendirian (biasanya berkaitan dengan keagamaan). ${ }^{8}$ Disebutkan juga bahawa fanatik adalah seerti dengan kalimah taasub iaitu terlalu kuat pegangannya atau berlebih-lebih keyakinannya pada sesuatu; tegar hati atau dinyatakan juga taasub sebagai kuat pegangan dan keyakinan yang keterlaluan terhadap sesuatu atau seseorang, seerti dengan fanatik. ${ }^{9}$

Kemudian, istilah fanatisme pula merujuk kepada satu fahaman atau perilaku yang menunjukkan sikap tarikan terhadap sesuatu secara berlebihan. George Santayana telah mendefinisikan fanatisme sebagai melipatgandakan usaha ada ketika anda lupa tujuan anda. ${ }^{10}$ Manakala Winston Churchill menyebutkan bahawa seseorang fanatisme sukar untuk mengubah pola berfikir dan tidak pula akan mengubah haluannya. Boleh dikatakan bahawa seseorang yang fanatik memiliki aturan yang ketat dalam pola berfikirnya dan cenderung tidak mahu mendengarkan pandangan atau idea yang dianggap bertentangan. ${ }^{11}$

Mohamad Kamil Hj. Abd. Majid dalam tulisan ada menyebutkan bahawa fanatik adalah sama maksud dengan taasub iaitu sikap yang keterlaluan dan melampau dalam sesuatu pegangan atau pendirian yang biasanya berkaitan dengan keagamaan. ${ }^{12}$ Sedangkan lawan bagi fanatik dan taasub ialah tasamuh dan toleransi; yang bermaksud lapang dada, luas fikiran

8 Dewan Bahasa dan Pustaka, "fanatik", laman sesawang Pusat Rujukan Persuratan Melayu, dicapai 11 Ogos 2016.http://prpm.dbp.gov.my/Search .aspx?k=fanatik

9 Dewan Bahasa dan Pustaka, "fanatik", laman sesawang Pusat Rujukan Persuratan Melayu, dicapai pada 11 Ogos 2016.http://prpm.dbp.gov.my /Search.aspx?k=fanatik.

10 George Santayana, Life of Reason: Reason in Common Sense (New York: Charles Scribner's Sons, 1905), 13.

11 George Santayana, Life of Reason: Reason in Common Sense, 13.

12 Mohamad Kamil Hj. Abd. Majid, "Fanatik dan Taksub Kepada Guru," laman sesawang Darul Kautsar Indeks, http://www.darulkautsar.net/darulkautsarnet/world/tasawwuf/fanatik-dan-taksub-kepada-guru.html. 
dan sabar. ${ }^{13}$ Bahkan, beliau juga memetik pandangan al-Qarḍāwī yang menyatakan bahawa sikap fanatik dan taasub kepada pandangan sendiri atau kepada guru dan kumpulan masing-masing adalah salah satu daripada gejala melampau-lampau. Sikap ini menggambarkan seseorang yang tidak berkemampuan membuka perbincangan untuk membandingkan pendapatnya dengan pendapat pihak-pihak lain bagi mendapat pendapat yang lebih kuat dalil dan alasannya. ${ }^{14}$

Menurut Achmad Mubarok MA pula, fanatik adalah suatu istilah yang digunakan untuk menyebut suatu keyakinan atau suatu pandangan tentang sesuatu yang bersifat positif atau negatif, tidak berasaskan kepada sandaran teori atau mempunyai asas kenyataan teori yang jelas tetapi dianuti atau dipegang dengan cara yang mendalam sehingga sukar untuk dibetulkan atau diubah pandangan tersebut. Fanatisme juga dapat disebut sebagai orientasi dan sentimen yang mempengaruhi seseorang dalam; berbuat sesuatu, menempuh sesuatu atau memberi sesuatu, dalam berfikir dan memutuskan, dalam mempersepsi dan memahami sesuatu, dan dalam merasa. ${ }^{15}$

Secara keseluruhannya, dapat difahami bahawa istilah ekstrem atau sikap ekstremis adalah keadaan di mana seseorang yang mempunyai sesuatu kepercayaan dalam dirinya dan merealisasikan apa yang dipercayai itu sekalipun melampaui batasan yang ditetapkan. Maka, akan terbitkan tindakan yang melampau-lampau, berlebih-lebihan, tindakan fanatik, taasub kepada apa yang disokong atau didukung dan sebagainya. Secara umumnya, ekstrem dan sikap ekstremis cenderung kepada tingkah laku negatif berbanding dengan positif.

13 Mohamad Kamil Hj. Abd. Majid, "Fanatik dan Taksub Kepada Guru," laman sesawang Darul Kautsar Indeks, http://www.darulkautsar.net/darulkautsarnet/world/tasawwuf/fanatik-dan-taksub-kepada-guru.html

${ }^{14}$ Muhammad Yusuf al-Qaradawi, Kebangunan Islam di Antara Tentangan dan Ekstrimisme, 41.

15 Achmad Mubarok MA. "Fanatik dan Toleransi", laman sesawang Mubarak Institute, dicapai 25 Julai 2016, http://mubarok-institute.blogspot.my/2010/12 /fanatik-dan-toleransi-oleh-prof-dr.html.. Rujuk juga Dinda Ayu Kusumaningtyas, "Fanatisme dan Radikalisme Agama". (Latihan Ilmiah di Jurusan Sistem Informasi, Sekolah Tinggi Manajemen Informatika dan Komputer, AMIKOM, Yogyakarta, 2011), 5. 


\section{Skop dan Metodologi}

Artikel ini secara umumnya akan memberikan penekanan terhadap pemahaman bagi istilah ekstrem daripada rujukan teks al-Quran dan hadith-hadith yang berkaitan. Memandangkan istilah ekstrem mempunyai maksud yang luas maka artikel ini akan cuba menumpukan dan membuat pilihan sesuai dengan skop perbincangannya.

Keseluruhannya, analisis terhadap teks al-Quran, hadith dan pandangan para ulama berkaitan berasaskan kepada analisis bersifat induktif dan deduktif. Bagi teks al-Quran dan hadith yang mendatangkan prinsip asas utama maka memerlukan kepada pendekatan induktif supaya dapat dijelaskan berasaskan kepada rujukan kepada pandangan para pentafsir dan pensyarah hadith sehingga segala yang bersifat prinsip yang khusus itu dapat dijelaskan kefahaman yang bersifat lebih luas pemahamannya. Manakala melalui analisis deduktif segala perbincangan yang dikemukakan dalam kalangan ulama dikumpulkan dan dianalisis sehingga dapat disimpulkan kefahaman yang menyeluruh dan bersifat khusus berkaitan dengan tema ekstrem ini. Gabungan antara kedua-dua pendekatan ini akan dapat memberikan penelitian yang jelas berkaitan dengan perbincangan terhadap tema ekstrem tersebut.

\section{Hasil dan Dapatan}

\section{Pertama: Ayat al-Quran Berkaitan dengan Ekstrem atau Melampau}

Istilah ekstrem dirujuk kepada perkataan Arab, iaitu ghuluw yang bermaksud taasub yang melampau dalam sesuatu perkara. ${ }^{16}$ Ia juga dirujuk dengan maksud melampaui had sempadan yang dibenarkan. Disebutkan istilah ghuluw ini dalam beberapa ayat alQuran seperti ayat 171 surah al-Nisa' dan surah al-Mā'idah ayat 77. Firman Allah SWT:

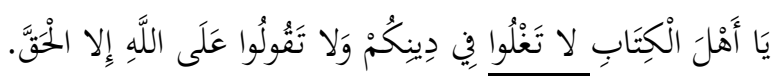

Al-Nisā' 4:171

\footnotetext{
16 "Ghuluw", laman sesawang al-Ma'ani, dicapai 3 Febuari 2016, http://www .almaany.com/ar/dict/ar-ar/\%D8\%BA\%D9\%84\%D9\%88/
} 
Terjemahan: "Wahai Ahli Kitab! Janganlah kamu melampaui batas dalam agamamu, dan janganlah kamu mengatakan terhadap Allah kecuali yang benar..."

Kemudian, firman Allah SWT:

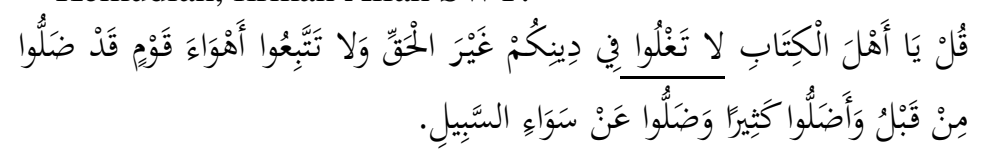

Al-Mā'idah 5:77

Terjemahan: "Katakanlah (Muhammad), wahai Ahli Kitab! Janganlah kamu berlebih-lebihan dengan cara yang tidak benar dalam agamamu. Dan janganlah kamu mengikuti keinginan orang-orang yang telah tersesat dahulu dan (telah) menyesatkan banyak (manusia), dan mereka sendiri tersesat dari jalan yang lurus."

Terdapat istilah lain yang digunakan untuk menggambarkan ghuluw iaitu ifrāt dan tafrìt, al-tamatțu' dan lain-lain lagi. Dalam surah al-Mā'idah, ayat 87 pula, Allah menggunakan istilah "almu 'tadīn" yang merujuk kepada golongan yang melampui batas. Asal ungkapan tersebut adalah kalimah i'tid̄' iaitu melampaui ketentuan syariat. Firman Allah SWT:
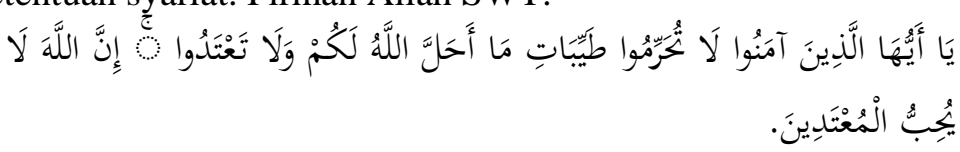

Al-Mā'idah 5:87

Terjemahan: "Hai orang-orang yang beriman, janganlah kamu mengharamkan sesuatu yang baik yang telah dihalalkan Allah bagimu, dan jangan pula kamu melampaui batas. Sesungguhnya Allah tidak menyukai orang-orang yang melampaui batas."

Dalam firman Allah:

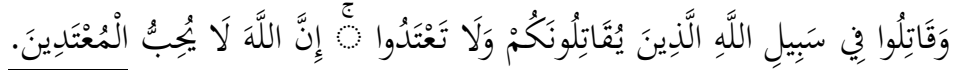

Al-Baqarah 2:190

Terjemahan:"Dan perangilah di jalan Allah orang-orang yang memerangi kamu, (tetapi) janganlah kamu melampaui batas, karena sesungguhnya Allah tidak menyukai orang-orang yang melampaui batas."

Kedua-dua ayat ini terkait rapat dengan keterangan dalam ayat 187 surah al-Baqarah ayat 187 di mana Allah SWT 
mempunyai batasan-batasan syariatNya dan larangan kepada setiap hamba untuk melebihkan had atau batasan yang ditetapkan itu. Firman Allah SWT:

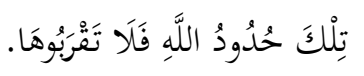

\section{Al-Baqarah 2:187}

Terjemahan: "Itulah batasan-batasan hukum Allah, maka janganlah kalian melampauinya."

Pada ayat dalam surah al-Nisā', perkataan ghuluw ini di ambil dari perkataan ghala, yaghlu dan secara bahasanya membawa maksud melampaui batas dan disertai juga berlebihlebih ${ }^{17}$. Al-Bukhari dalam kitab Sahihnya berdalilkan dengan surah al-Nisa' ini dengan ayat yang ditujukan kepada ahli kitab itu adalah dalam bentuk konteks yang umum iaitu selain dari kaum Yahudi dan Nasrani. Oleh itu, umat Islam khususnya tidak dikecualikan daripada maksud ayat ini supaya mereka tidak terjebak dalam perbuatan ghuluw yang dilakukan sebelum mereka $^{18}$.

Kemudian, al-Quran turut menggunakan istilah lain yang turut merujuk kepada sikap dan tindakan ekstrem iaitu takalluf iaitu merujuk kepada maksud memaksa-maksa diri. Ia merujuk kepada memaksa diri dengan perkara yang tidak dapat ditanggung, sesuai dengan ciri agama Islam yang mudah serta tidak membebankan. Firman Allah SWT:

\section{Sad 38:86}

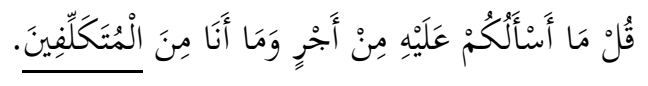

Terjemahan: "Katakanlah (hai Muhammad): "Aku tidak meminta upah sedikitpun padamu atas dakwahku dan bukanlah aku termasuk orang-orang yang mengada-adakan."

Justeru, kesemua istilah tersebut dapat dikatakan bahawa menggambarkan kepada sikap melampaui, membebankan, melebihi had dan sempadan yang dibenarkan. Dengan itu, ghuluw bermaksud melampaui had dan terkeluar daripada sempadan yang ditetapkan. $^{19}$

17 Muḥammad ibn Mukarram ibn 'Alī ibn Aḥmad Ibn Manẓūr, Lisān al- 'Arab (Kaherah: Dār al-Ma'ārif, t.t.), 9:113.

18 Ibn Hajar al-Asqalani, Fathul Bari: Penjelasan Kitab Shahih al-Bukhari, terj Amir al-Din, ed. Abu Rania (Jakarta: Pustaka Azzam, 2011), 6: 233.

19 Ibn Manzuūr, Lisan al-Arab, bil. 37, 329, entri "ghalä". 
Manakala golongan ekstremis pula adalah merujuk kepada orang yang tidak mempedulikan apa-apa had di dalam setiap pemikiran ucapan dan tindakannya. Akan tetapi, di dalam setiap perkara itu terdapat had yang telah ditetapkan oleh Allah SWT. Seperti terdapat banyak firman Allah SWT di dalam al-Quran yang mengingatkan tentang aturan Allah (hudūd Allāh) dan melampaui had yang telah Allah tetapkan adalah suatu pengkhianatan, kafir, munafik, jahil dan zalim.

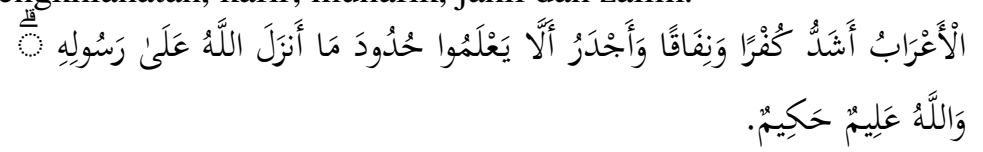

Al-Tawbah 9:97

Terjemahan: Orang-orang Arab lebih keras kufurnya dan sikap munafiknya, dan sangatlah patut mereka tidak mengetahui batas-batas (dan hukum-hukum Syarak) yang diturunkan oleh Allah kepada RasulNya. Dan (ingatlah) Allah Maha Mengetahui, lagi Maha Bijaksana.

Firman Allah:

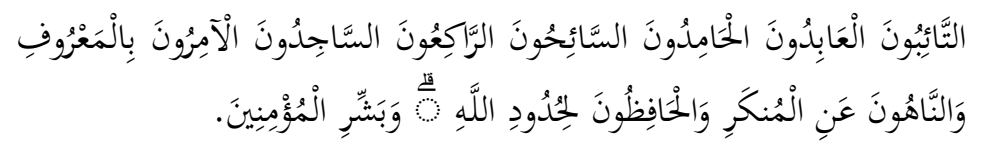

Al-Tawbah 9:112

Terjemahan: (Mereka itu ialah): orang-orang yang bertaubat, yang beribadat, yang memuji Allah, yang mengembara (untuk menuntut ilmu dan mengembangkan Islam), yang rukuk, yang sujud, yang menyuruh berbuat kebaikan dan yang melarang daripada kejahatan, serta yang menjaga batas-batas hukum Allah. Dan gembirakanlah orang-orang yang beriman (yang bersifat demikian).

Selain daripada itu, ghuluw juga bermaksud menghantar sesuatu seperti kejahatan dan penyakit kepada orang lain. ${ }^{20} \mathrm{Hal}$ ini seperti apa yang telah dilakukan oleh golongan ini kepada agama supaya bercampur di dalam agama antara kebenaran dan kepalsuan sehingga ke tahap kebenaran tidak lagi diiktiraf. Dan kesannya, ramai yang sesat berikutan daripada keinginan yang

${ }^{20}$ Md Asham bin Ahmad. "Moderation in Islam: A Conseptual Analysis of Wasatiyyah", TAFHIM: IKIM Journal of Islam and the Contemporary World 4, (2011): 29-46, 43. 
tidak telus itu berbanding dengan ilmu pengetahuan yang sebenar. ${ }^{21}$

Oleh yang demikian, dapat dikatakan bahawa perkataan ghuluw ini sinonim dengan perkataan ekstrem yang lebih difahami pada hari ini. Menurut Kamus Dewan ekstrem bermaksud keterlaluan atau melampau. ${ }^{22}$ Manakala ekstremis adalah orang yang melampau atau orang (golongan) yang sikapnya (pendiriannya) dalam sesuatu hal (seperti politik) melampau batas kesederhanaan. $^{23}$

Walau bagaimanapun, istilah ghuluw atau ekstrem juga turut dilihat dari sudut memahami fikiran mereka yang terlibat secara langsung dan mereka yang menyokong tindakan ekstremis dan keganasan agama itu, pembentukan imaginasi agama pada pelaku dan pergerakan ahli ekstremisme agama. ${ }^{24}$ Ia tidak tertumpu hanya kepada pelaku ekstremis agama ini semata-mata sahaja.

Jadual 1.0: Istilah Ekstrem dan Skop Maknanya dalam al-Quran

\begin{tabular}{|c|c|c|c|}
\hline Bil & $\begin{array}{l}\text { Nama surah dan } \\
\text { nombor ayat }\end{array}$ & $\begin{array}{l}\text { Istilah dalam } \\
\text { al-Quran }\end{array}$ & $\begin{array}{l}\text { Maksud kalimah/ } \\
\text { batasan makna }\end{array}$ \\
\hline 1 & al-Nisā' 4:171 & \multirow[b]{2}{*}{ Al-Ghuluw } & \multirow{2}{*}{$\begin{array}{l}\text { Sikap melampaui, } \\
\text { ekstrem, fanatik, } \\
\text { membebankan, } \\
\text { melebihi had. }\end{array}$} \\
\hline 2 & al-Mā’idah 5:77 & & \\
\hline 3 & al-Mā'idah 5:87 & \multirow{2}{*}{ Al-Mu'tadīn } & \multirow{2}{*}{$\begin{array}{l}\text { Orang yang bersikap } \\
\text { melampaui batas }\end{array}$} \\
\hline 4 & Al-Baqarah (2):190 & & \\
\hline 5 & Șad 38:86 & $\begin{array}{l}\text { Takalluf / al- } \\
\text { Mutakallafin }\end{array}$ & $\begin{array}{l}\text { Memaksa-maksa diri/ } \\
\text { Sikap membebani diri }\end{array}$ \\
\hline 6 & Al-Baqarah 2:187 & \multirow{3}{*}{$\begin{array}{l}\text { Melampaui } \\
\text { Had / Hudūd }\end{array}$} & \multirow{3}{*}{$\begin{array}{l}\text { Tindakan yang } \\
\text { melampaui batas } \\
\text { syarak; melampaui had } \\
\text { yang ditentukan }\end{array}$} \\
\hline 7 & al-Tawbah 9:97 & & \\
\hline 8 & al-Tawbah 9:112 & & \\
\hline
\end{tabular}

Sumber: Hasil Analisis Pengkaji

${ }^{21}$ Md Asham bin Ahmad. "Moderation in Islam: A Conseptual Analysis of Wasatiyyah", 43.

22 Dewan Bahasa dan Pustaka, "ekstreme", laman sesawang Pusat Rujukan Persuratan Melayu, dicapai 4 Febuari 2016, http://prpm.dbp.gov.my/Search .aspx?k=ekstreme

23 Dewan Bahasa dan Pustaka, "ekstreme", laman sesawang Pusat Rujukan Persuratan Melayu, dicapai 4 Febuari 2016, http://prpm.dbp.gov.my/Search .aspx?k=ekstreme

24 Mansor Mohd Noor. "Memahami dan Mengurus Ekstremeisme Agama di Malaysia", Journal of Ethics, Legal and Govermance 1 (2005), 53. 


\section{Hadith-hadith Berkaitan dengan Ekstrem atau Melampau}

Kemudian, dalam perbincangan terhadap hadith-hadith daripada al-Kutub al-Sittah istilah ekstrem dapat dirujuk kepada beberapa istilah dan skop maknanya yang dijelaskan oleh Nabi SAW.

Jadual 1.0: Taburan Hadith Ekstrem atau al-Ghuluw dalam al-Kutub al-Sittah

\begin{tabular}{|c|c|c|c|c|c|c|c|}
\hline Bil. & Tema dan atraf Hadith & \multicolumn{6}{|c|}{ Sumber dan Bilangan* } \\
\hline $\begin{array}{c}\text { Tema } \\
\text { I }\end{array}$ & $\begin{array}{l}\text { Larangan Melampaui Batas, } \\
\text { Ekstrem atau Memberatkan } \\
\text { Sesuatu }\end{array}$ & $\begin{array}{l}\text { S } \\
B\end{array}$ & $\begin{array}{c}\mathrm{S} \\
\mathrm{M}\end{array}$ & $\begin{array}{l}\mathrm{J} \\
\mathrm{T}\end{array}$ & $\begin{array}{l}\text { S } \\
\mathrm{D}\end{array}$ & $\begin{array}{l}\mathrm{S} \\
\mathrm{N}\end{array}$ & $\begin{array}{l}\text { S } \\
\text { I }\end{array}$ \\
\hline 1. & هَلَكَ الْمُتَنَطُّعُونَ قَالَهَا ثَلَاثَ & - & 1 & - & 1 & - & - \\
\hline 2. & هُهُيْنَا عَنِ التَّكَلُّفِ & 1 & - & - & - & - & - \\
\hline 3. & 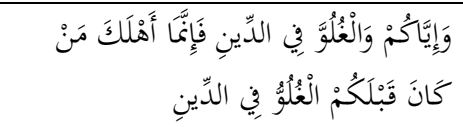 & - & - & - & - & 1 & 1 \\
\hline $\begin{array}{c}\text { Tema } \\
\text { II }\end{array}$ & $\begin{array}{l}\text { Larangan Bersikap Ghuluw } \\
\text { Kerana Menyalahi Fitrah } \\
\text { dalam Beribadah }\end{array}$ & $\begin{array}{l}\text { S } \\
\text { B }\end{array}$ & $\begin{array}{c}\mathrm{S} \\
\mathrm{M}\end{array}$ & $\begin{array}{l}\mathrm{J} \\
\mathrm{T}\end{array}$ & $\begin{array}{l}S \\
D\end{array}$ & $\begin{array}{l}\mathrm{S} \\
\mathrm{N}\end{array}$ & $\begin{array}{l}\text { S } \\
\text { I }\end{array}$ \\
\hline 4. & 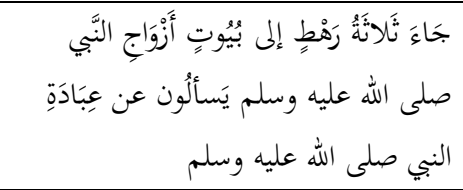 & 1 & 1 & - & - & 1 & - \\
\hline 5. & 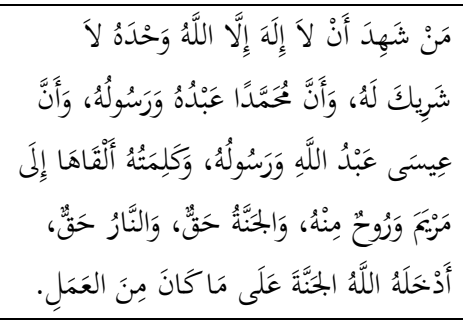 & 1 & - & - & - & - & - \\
\hline $\begin{array}{c}\text { Tema } \\
\text { III }\end{array}$ & $\begin{array}{l}\text { Larangan Bersikap Taasub } \\
\text { Kepada Suatu Kumpulan atau } \\
\text { Mengajak Kepadanya }\end{array}$ & $\begin{array}{l}\text { S } \\
\text { B }\end{array}$ & $\begin{array}{c}\mathrm{S} \\
\mathrm{M}\end{array}$ & $\begin{array}{l}\mathrm{J} \\
\mathrm{T}\end{array}$ & $\begin{array}{l}\mathrm{S} \\
\mathrm{D}\end{array}$ & $\begin{array}{l}\mathrm{S} \\
\mathrm{N}\end{array}$ & $\begin{array}{l}\text { S } \\
\text { I }\end{array}$ \\
\hline 6. & 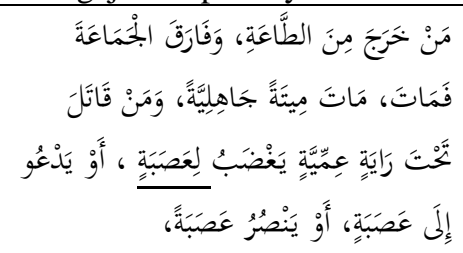 & - & 2 & - & - & 1 & - \\
\hline
\end{tabular}




\begin{tabular}{|c|c|c|c|c|c|c|c|}
\hline Bil. & Tema dan atraf Hadith & \multicolumn{6}{|c|}{ Sumber dan Bilangan* } \\
\hline $\begin{array}{c}\text { Tema } \\
\text { IV }\end{array}$ & $\begin{array}{l}\text { Larangan Solat Sunat } \\
\text { Berlebihan \& Ibadah Fardu } \\
\text { Sebagai Had Minimun dalam } \\
\text { Ibadah Solat }\end{array}$ & $\begin{array}{l}\text { S } \\
\text { B }\end{array}$ & $\begin{array}{c}\mathrm{S} \\
\mathrm{M}\end{array}$ & $\begin{array}{l}\mathrm{J} \\
\mathrm{T}\end{array}$ & $\begin{array}{l}S \\
D\end{array}$ & $\begin{array}{c}\mathrm{S} \\
\mathrm{N}\end{array}$ & $\begin{array}{l}\text { S } \\
\text { I }\end{array}$ \\
\hline 7. & 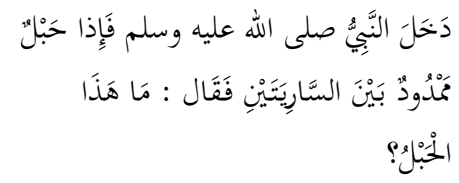 & 1 & 1 & - & 1 & 1 & 1 \\
\hline 8. & 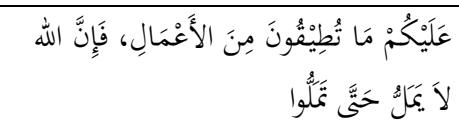 & 2 & - & - & - & - & - \\
\hline 9. & 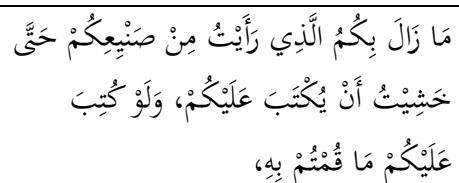 & 2 & - & - & - & - & - \\
\hline 10. & 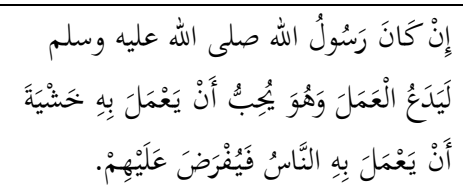 & 1 & - & - & - & - & - \\
\hline $\begin{array}{c}\text { Tema } \\
\mathrm{V}\end{array}$ & $\begin{array}{l}\text { Larangan Berpuasa atau } \\
\text { Menyambung Puasa Sehingga } \\
\text { Membebankan Diri serta } \\
\text { Ibadah Puasa Sunat Nabi } \\
\text { Dawud AS adalah Had } \\
\text { Maksimum Dalam Ibadah } \\
\text { Puasa }\end{array}$ & $\begin{array}{l}\text { S } \\
\text { B }\end{array}$ & $\begin{array}{c}\mathrm{S} \\
\mathrm{M}\end{array}$ & $\begin{array}{l}\mathrm{J} \\
\mathrm{T}\end{array}$ & $\begin{array}{l}\text { S } \\
\mathrm{D}\end{array}$ & $\begin{array}{c}\mathrm{S} \\
\mathrm{N}\end{array}$ & $\begin{array}{l}\text { S } \\
\text { I }\end{array}$ \\
\hline 11. & 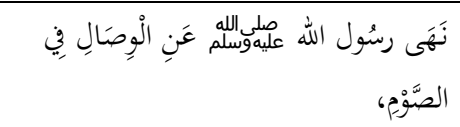 & 1 & - & - & - & - & - \\
\hline 12. & 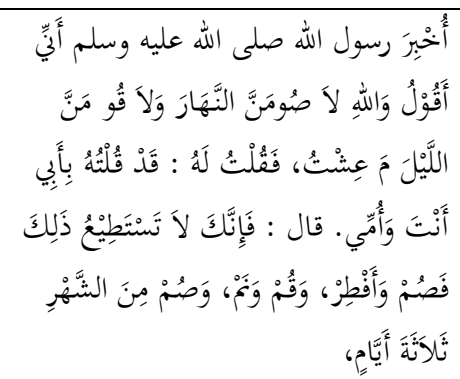 & 1 & - & - & - & - & - \\
\hline
\end{tabular}




\begin{tabular}{|c|c|c|c|c|c|c|c|}
\hline Bil. & Tema dan atraf Hadith & \multicolumn{6}{|c|}{ Sumber dan Bilangan* } \\
\hline 13. & لَيَسَ الْبِرُ أَنْن تَصُومُوما فِي السَّفَرِ & 1 & 1 & 1 & 1 & 1 & 1 \\
\hline 14. & 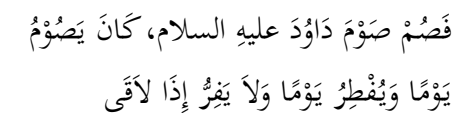 & 6 & 6 & - & 1 & 9 & 1 \\
\hline $\begin{array}{c}\text { Tema } \\
\text { VI }\end{array}$ & $\begin{array}{l}\text { Larangan Berdoa Secara Paksa } \\
\text { atau Berlebihan }\end{array}$ & $\begin{array}{l}\mathrm{S} \\
\mathrm{B}\end{array}$ & $\begin{array}{l}\mathrm{S} \\
\mathrm{M}\end{array}$ & $\begin{array}{l}\mathrm{J} \\
\mathrm{T}\end{array}$ & $\begin{array}{l}S \\
D\end{array}$ & $\begin{array}{l}\mathrm{S} \\
\mathrm{N}\end{array}$ & $\begin{array}{l}\mathrm{S} \\
\mathrm{I}\end{array}$ \\
\hline 15. & 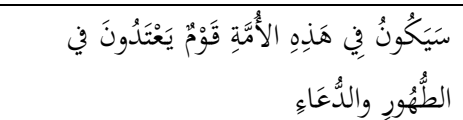 & - & - & - & 1 & - & 1 \\
\hline 16. & 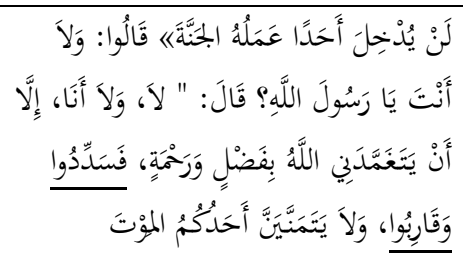 & 1 & - & - & - & - & - \\
\hline \begin{tabular}{|c|} 
Tema \\
VII
\end{tabular} & $\begin{array}{l}\text { Larangan Memuji Nabi } \\
\text { Berlebihan }\end{array}$ & $\begin{array}{l}\mathrm{S} \\
\mathrm{B}\end{array}$ & $\begin{array}{l}\mathrm{S} \\
\mathrm{M}\end{array}$ & $\begin{array}{l}\mathrm{J} \\
\mathrm{T}\end{array}$ & $\begin{array}{l}S \\
D\end{array}$ & $\begin{array}{l}\mathrm{S} \\
\mathrm{N}\end{array}$ & $\begin{array}{l}\mathrm{S} \\
\mathrm{I}\end{array}$ \\
\hline 17. & 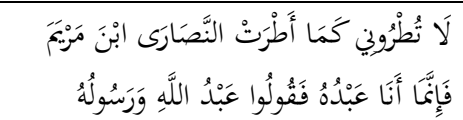 & 2 & - & - & - & - & - \\
\hline $\begin{array}{c}\text { Tema } \\
\text { VIII }\end{array}$ & $\begin{array}{l}\text { Larangan Mengada-adakan } \\
\text { Sesuatu Baharu Berkaitan } \\
\text { Agama }\end{array}$ & $\begin{array}{l}\text { S } \\
\text { B }\end{array}$ & $\begin{array}{l}\mathrm{S} \\
\mathrm{M}\end{array}$ & $\begin{array}{l}\mathrm{J} \\
\mathrm{T}\end{array}$ & $\begin{array}{l}S \\
D\end{array}$ & $\begin{array}{l}\mathrm{S} \\
\mathrm{N}\end{array}$ & $\begin{array}{l}\text { S } \\
\text { I }\end{array}$ \\
\hline 18. & رَرُّنُ & 1 & 1 & - & 1 & - & 1 \\
\hline \begin{tabular}{|c|} 
Tema \\
IX \\
\end{tabular} & $\begin{array}{l}\text { Agama Tidak Memberatkan/ } \\
\text { Membebankan }\end{array}$ & $\begin{array}{l}\mathrm{S} \\
\mathrm{B}\end{array}$ & $\begin{array}{l}\mathrm{S} \\
\mathrm{M}\end{array}$ & $\begin{array}{l}\mathrm{J} \\
\mathrm{T} \\
\end{array}$ & $\begin{array}{l}\mathrm{S} \\
\mathrm{D}\end{array}$ & $\begin{array}{l}\mathrm{S} \\
\mathrm{N}\end{array}$ & $\begin{array}{l}\mathrm{S} \\
\mathrm{I}\end{array}$ \\
\hline 19. & 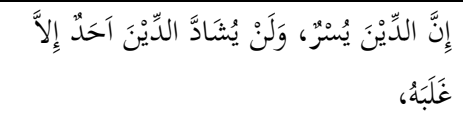 & 2 & - & - & - & 1 & - \\
\hline
\end{tabular}

*SB: Șahịị al-Bukhārīi; SM: Șahịị Muslim; JM: Jāmi` al-Tirmīdhī; SD: Sunan Abū Dāwūd, SN: Sunan al-Nasā’̄ī; SI: Sunan Ibn Mājah

Sumber: Hasil Analisis daripada al-Kutub al-Sittah

Daripada keseluruhan hadith ini, perbincangan hanya memfokuskan kepada aspek teori dan pemahaman secara umum terhadap ekstrem yang tidak melibatkan kepada penekanan terhadap aspek contoh dan bentuk-bentuk ekstrem. Jadi, daripada keseluruhan itu dalam al-Kutub al-Sittah, terdapat lima hadith 
yang menjadi asas perbincangan utama dari sudut pemahaman berkaitan dengan ekstrem atau melampau. Kelima-lima hadith itu dapat dibahagikan kepada tiga tema atau topik utama iaitu:

\section{Pertama: Larangan Melampaui Batas, Ekstrem atau Memberatkan Sesuatu Hadith 1: Hadith Larangan Menjadi Orang yang Melampaui Batas (al-Mutații 'ün)}

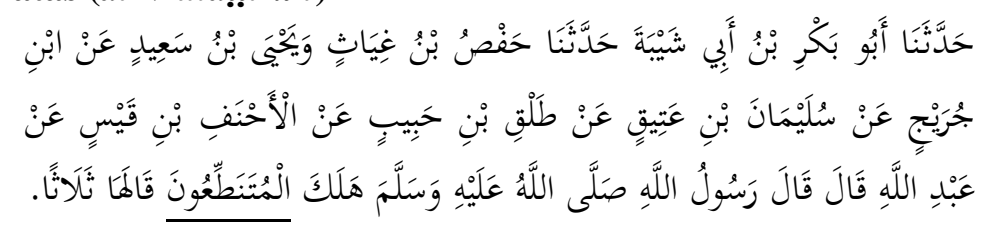

Terjemahan : "Telah menceritakan kepada kami Abū Bakar bin Abī Shaybah telah menceritakan kepada kami Hafṣ bin Ghiyath dan Yahyā bin Sa'īd dari Ibn Jurayj dari Sulaymān bin 'Atīq dari Talq bin Habīb dari Al-Ahnaf bin Qays dari "Abd Allāh dia berkata; "Rasulullah SAW teIah bersabda: "Celakalah orang-orang yang suka melampaui batas." (Beliau mengucapkannya tiga kali). ${ }^{25}$

Dalam hadith ini, ungkapan halaka al-mutanațti' ün yang bermaksud: "celakalah orang-orang yang suka melampaui batas," yang bermaksud golongan yang ekstremis. Golongan ekstrem ini dibicarakan sebagai orang-orang yang mengkaji sesuatu dan kemudiannya mereka bersikap ekstremis terhadap apa yang dikajinya. Golongan ini adalah orang yang melampaui batas dalam percakapan dan perbuatan. Dikatakan bahawa golongan ini apabila dia makan kemudian dia akan mengembalikannya semula, iaitu ayat ini bermaksud orang yang ekstremis ini adalah seorang yang mengkhianati prinsipnya sendiri, serta melampaui batas (ekstrem) iaitu dia membohongi sesuatu fakta apabila mendalami dan

\footnotetext{
${ }^{25}$ Hadith riwayat Muslim, Kitab al-'Ilm, Bāb Halaka al-Mutanatți'ūn, no.hadith 6784, dan. Sunan Abū Dāwūd, Kitāb al-Sunnah, Bab fì luzūmi al-Sunnah, no.hadith 4608. Rujuk Muslim bin al-Hajjāj Abu Husain al-Qushairi alNaysābūrī, "Ṣahịịh Muslim", dalam Mawsū'at al-Hadīth al-Sharîf: al-Kutub al-Sittah, ed. Șalih bin 'Abd al- 'Aziz Al al-Shaykh (Riyadh: Dār al-Salām, 2000) 1143 dan lihat Abū Dāwūd Sulaymān bin al-Ash'ath bin Isḥāq al-Azīdī al-Sijistān̄i, "Sunan Abū Dāwūd", dalam Mawsū'at al-Hadīth al-Sharīf: alKutub al-Sittah, ed. Șalih bin 'Abd al- 'Aziz Al al-Shaykh (Riyadh: Dār alSalām, 2000), 1561.
} 
mempelajari sesuatu perkara. Dalam hadith ini, telah dinyatakan larangan supaya menghindari dari perbuatan tanattu', tashaddud iaitu sikap mengada-adakan. ${ }^{26}$ Menurut al-Khattabi, al-mutanatti ' $\bar{u} n$ ini adalah mereka yang suka mengada-adakan dalam perkara dan para ahli kalam menyatakan bahawa perkara yang tidak tercapai oleh akal atau tidak logik termasuk dalam perbuatan melampaui batas. Perkataan thaläth marrāt bermaksud perkataan ekstrem ini telah ditegaskan dan diulang sebanyak tiga kali. ${ }^{27}$

Hadith mengenai larangan ini telah diucapkan oleh baginda Rasulullah SAW sebanyak tiga kali pada perkataan halaka almutanatți'ün, dan ia menunjukkan bahawa Rasullullah SAW sangat tidak menyukai dengan perbuatan ini dan mencela bagi sesiapa yang melakukannya. Golongan yang ekstrem dalam agama kebiasaannya akan berkata mengenai Allah SWT tanpa hak dan membicarakan tentang hal-hal agama tanpa ilmu dan sehingga akhirnya yang akan menyesatkan diri sendiri berserta orang lain kerana sikap dan perbuatan ghuluw ini adalah antara penyebab kepada penyimpangan dalam agama, sikap dan perbuatan.

\section{Hadith 2: Hadith Larangan Membebani Diri (al-Takalluf)}

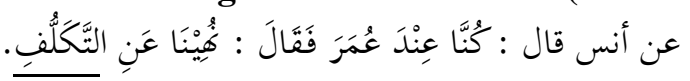

Terjemahan: Dari Anas beliau berkata, "Kami pernah berada di sisi Umar, maka beliau berkata: "Kita dilarang membebani diri." 28

Al-Bukhārī telah menyatakan berkenaan hadith ini secara ringkas. Beliau meletakkan hadith di dalam bab Mā Yukrah min Kathrah al-Su'āl wa Takalluf mā là Ya 'nīh dan mengaitkan bab ini dengan ayat 101 surah al-Mā'idah, firman Allah SWT:

${ }^{26}$ Mūsā Syāhīn Lashīn, Fath al-Mu 'in Sharh Ṣahīh Muslim (Kaherah: Dār alSyuruq, 2002), 10:214.

27 Ab̄̄ Țayyib Muhammad Shams al-Ḥaq, Awn al-Ma'būd Sharh Sunan Abī $D \bar{a} w \bar{u} d$, ed. 'Abd al-Raḥman Muhammad 'Uthmān (Madinah: Maktabah alSalāfiyah,1968), 12:362.

28 Hadith riwayat al-Bukhārī, Kitāb al-I'tiṣam bi al-Kitāb wa Sunnah, Bāb banyak bertanya dan membebani diri dengan hal yang tidak penting yang dimakruhkan, no.hadith 7293. Abū 'Abd Allāh Muḥammad bin Ismā'îl alBukhārī, "Șahịḥ al-Bukhārī”, dalam Mawsū'at al-Hadīth al-Sharīf: al-Kutub al-Sittah, ed. Șāliḥ bin 'Abd al-'Azīz Al al-Shaykh (Riyadh: Dār al-Salām, 2000), 607. 


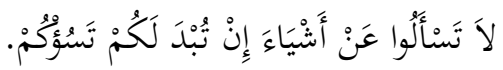

Terjemahan: "Janganlah kamu bertanyakan (kepada Nabi) perkara-perkara yang jika diterangkan kepada kamu akan menyusahkan (membebani) kamu."

Jelas daripada perletakkan al-Bukhārī dalam bab tersebut bagi mengambarkan dan menjelaskan tentang larangan bertanyakan sesuatu yang akhirnya akan memberi bebanan atau menyusahkan diri yang bertanya tersebut. Ia juga berkait rapat dengan ayat tersebut. Dalam bab ini juga al-Bukhārī menghimpunkan dengan lapan lagi hadith yang keseluruhannya menjelaskan lagi berkaitan dengan pertanyaan yang banyak dalam hal yang tidak perlu sehingga akhirnya membebankan diri sendiri.

Manakala al-Humaydī telah menyebutkan bahawa dalam riwayat lain dari Thābit, dari Anas:

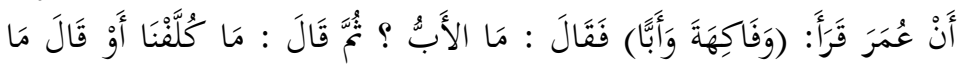

$$
\begin{aligned}
& \text { أُُْْرْنَا بهمَذَا. }
\end{aligned}
$$

Terjemahan: "Bahawa Umar membaca, "wa fäkihah wa $a b b \bar{a}$." Maka beliau berkata, "Apakah itu abbā?" Umar kemudian menjawab, "kita tidak dibebani - atau berkata kita tidak diperintahkan terhadap hal ini.". ${ }^{29}$

Dalam hadith ini telah menyatakan larangan berkenaan untuk membebani diri sendiri, ia menunjukkan para sahabat dilarang untuk membebani diri mereka dengan perkataan 'umirna iaitu kami diperintahkan atau perkataan nuhīna bermaksud kami dilarang, dan keduanya membawa hukum yang sama dengan dinisbahkan langsung kepada Rasulullah SAW, walaupun periwayatannya tidak menisbahkan secara terus atau terangterangan kepada Nabi SAW, namun ianya cukup untuk menegaskan maksud dari hadith ini supaya sahabat dan selainnya tidak mengamalkan sikap membebankan diri dalam setiap perkara. Oleh sebab itu, hadith ini telah dibatasi dengan perkataan nuhīna 'an al-takalluf. ${ }^{30}$ Perbuatan membebani diri mempunyai maksud yang sama dengan perbuatan ekstrem, dan sama ada berkaitan ibadah ataupun hal lainnya. Sikap membebani diri ini boleh

${ }^{29}$ Ibn Hajar al-Asqalani, Fathul Bari: Penjelasan Kitab Shahih al-Bukhari, 36:91.

30 Ibn Hajar al-Asqalani, Fathul Bari: Penjelasan Kitab Shahih al-Bukhari, 95. 
mengundang kebinasaan pada diri akhirnya. Pada hadith lain pula, Nabi SAW menyuruh agar manusia melaksanakan perintah sesuai dengan kemampuan diri. Daripada Abi Hurayrah RA daripada Nabi SAW bersabda:

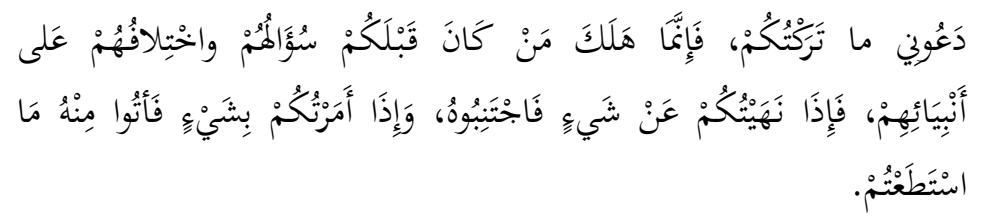

Terjemahan: "Tinggalkan apa yang telah aku tinggalkan kepada kamu. Sesungguhnya binasanya orang-orang sebelum kamu adalah kerana mereka banyak bertanya dan banyak perselisihan (penentangan) terhadap para nabi mereka. Maka, apabila aku melarang (menegah) sesuatu akan jauhilah ia, dan apabila aku perintahkan kamu dengan sesuatu perintah, lakukanlah sesuai dengan kemampuan kamu." ${ }^{31}$

Hadith ini menunjukkan bahawa supaya setiap apa yang dilarang oleh Rasulullah SAW perlu ditinggalkan seluruhnya kecuali terdapat keuzuran yang membolehkannya. Disebutkan juga dalam hadith "Sesungguhnya binasanya orang-orang sebelum kamu adalah kerana mereka banyak bertanya dan banyak perselisihan (penentangan) terhadap para nabi mereka," iaitu disebabkan pertanyaan yang dikemukakan terhadap sesuatu yang tidak diharamkan pada mulanya, lalu diharamkan kerana pertanyaan yang mendalam sehingga membebankan diri. Justeru itu, perlunya untuk menjauhi semua larangan Rasulullah SAW dan apa yang dilarang oleh Allah SWT jika sesuatu larangan tersebut menunjukkan haram bukan makruh.

Hadith ini juga menyuruh sesiapa yang tidak mampu untuk melakukan perbuatan yang diperintahkan secara keseluruhan, cukuplah hanya melaksanakan sebahagiannya mengikut kemampuan. Allah SWT tidak membebani seseorang kecuali mengikut kadar kemampuannya menunjukkan agama Islam yang mudah. ${ }^{32}$ Sesuai dengan firman Allah SWT pada ayat 285, surah

${ }^{31}$ Hadith riwayat al-Bukhārī, Kitāb al-I'tișām bi al-Kitāb wa Sunnah, Bāb alIqtidā'i bi Sunan Rasul SAW, no.hadith 7288. Lihat al-Bukhārī, "Șaḥị̣ alBukhārī”, dalam Mawsū 'at al-Hadìth al-Sharīf, 607.

32 Marwan Hadidi, S.PdI, Artikel: Perintah yang Disesuaikan dengan Kemampuan (Jakarta: Yayasan Pendidikan Islam al-Atsary, 2014), 23. 
al-Baqarah yang bermaksud: "Allah tidak memberati seseorang melainkan apa yang terdaya olehnya."

\section{Hadith 3: Hadith Larangan Sikap Berlebih-lebihan (al- Ghuluw) dalam Agama yang Membinasakan Umat Sebelumnya.}

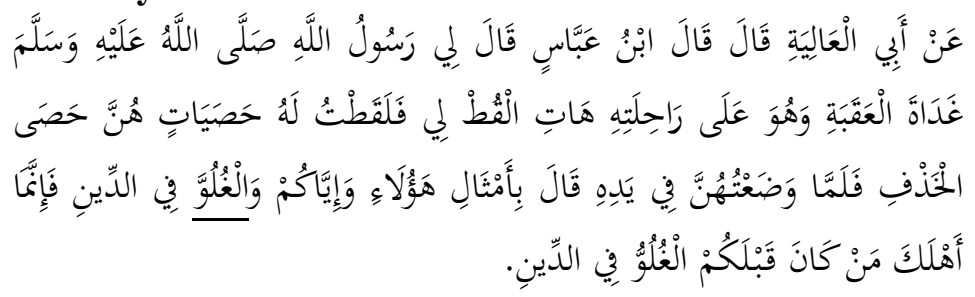

Terjemahan: "Dari Abū Al-'Āliyah, berkata; Ibn 'Abbās berkata; Rasulullah SAW bersabda kepadaku pada pagi hari di "Aqabah dan baginda berada di atas kenderaannya: "Ambilkan untukku," lalu aku mengambilkan beberapa batu kecil untuk baginda iaitu batul untuk melontar. Ketika aku meletakkan di tangan baginda, lalu baginda bersabda dengan memberi misalan batu-batu kecil itu: "Janganlah kamu berlebih-lebihan dalam agama, kerana sesungguhnya yang telah membinasakan orang-orang sebelum kalian adalah sikap berlebih-lebihan (ghuluw) dalam agama." ${ }^{33}$

Hadith ini diriwayatkan oleh al-Nasā' $\overline{1}$ dan Ibn Mājah serta tidak diriwayatkan oleh al-Bukhārī dan Muslim. Walaupun demikian, al-Bukhārī telah meletakkan satu bab yang di dalam kitabnya, membicarakan tentang ghuluw (melampau) iaitu pada Kitab al-I'tișam bi al-Kitāb, Bab Mā Yukrah min al-Ta 'ammuq wa al-Tanāzu' fì al-'Ilm wa al-Ghuluww fì al-Dìn wa al-Bida' (Bab Perkara yang Dibenci iaitu Mendalami (Bertanya Secara Mendalam) dan Berbalah dalam Ilmu dan Melampau dalam

${ }^{33}$ Hadith riwayat al-Nasā'̄i, Kitab Manāsik al-Ḥāj, Bāb al-Tiqat al-Hasa, no.hadith 3059, dan Sunan Ibn Mājah, Kitab Manāsik al-Ḥāj, Bāb kadar kerikil untuk lemparan, no.hadith 3029. Rujuk Abū 'Abd al-Raḥman Aḥmad

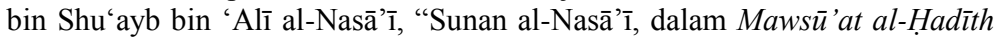
al-Sharīf: al-Kutub al-Sittah, ed. Șālih bin 'Abd al-'Aziz Al al-Shaykh (Riyadh: Dār al-Salām, 2000), 2284 dan Abū 'Abd Allāh Muhammad bin Yazīd al-Qazwaynī, "Sunan Ibn Mājah", dalam Mawsū'at al-Hadìth al-Sharīf: al-Kutub al-Sittah, ed. Șālih bin 'Abd al-'Azīz Al al-Shaykh (Riyadh: Dār alSalām, 2000), 2658. 
Beragama Serta (Perbuatan) Bidaah). Lalu dikaitkan dengan ayat 171 surah al-Nisā':

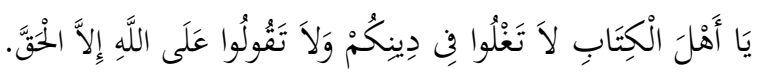

Terjemahannya: "Wahai Ahli kitab (Yahudi dan Nasrani)! Janganlah kamu melampaui batas dalam perkara agama kamu, dan janganlah kamu mengatakan sesuatu terhadap Allah melainkan yang benar."

Badr al-Dīn al-'Aynī menyebutkan bahawa pada tarjamah alBāb bagi Șaḥịh al-Bukhārī itu menjelaskan bahawa apa yang dibenci daripada mendalami (perbuatan bertanya secara terlalu mendalam) iaitu bersangatan dalam sesuatu perkara sehingga melampaui had (yang ditetapkan). Manakala al-Tanāzu (Berbalah) dalam ilmu iaitu memberi maksud saling bertengkar pada ilmu ketika berlaku khilaf (perselisihan pandangan) pada suatu hukum apabila tidak jelas dalilnya. Manakala al-Ghuluw itu merujuk kepada maksud melampaui had. ${ }^{34}$ Menurut al-Kirmān̄, al-Ghuluw (melampau batas) adalah lebih atas (atau lebih mendalam) berbanding al-Ta 'ammuq. Lalu al-'Aynī mengaitkan dengan hadith yang dibincangkan di atas. Beliau memberikan contoh seperti perbincangan berkaitan sifat rububiyyah sehingga menimbulkan perbalahan daripada perbalahan syaitan yang membawa kepada terkeluar daripada kebenaran yang sebenar. Manakala sifat ghuluw pada fikrah (pemikiran) yang memikirkan tentang ketuhanan sehingga membawa kepada menjadikan tuhan (yakni Allah) tiga (iaitu mensyirikkan Allah SWT). Demikian dimaksudkan bahawa sifat ghuluw (melampau) ini membawa kesan buruk yang besar. Sedangkan al-Bida' (bidaah) adalah merujuk kepada sesuatu yang tidak ada asal daripada al-Kitab (yakni al-Quran) dan al-Sunnah atau dikatakan juga menzahirkan atau mengadakan sesuatu yang tidak ada pada zaman Nabi SAW dan tidak pula ada pada zaman para Sahabat RA. ${ }^{35}$

Demikian juga Ibn Hajar yang menyebutkan tentang hal yang sama seperti disebutkan oleh al-'Aini. Beliau juga menyatakan alGhuluw adalah bersangatan dalam sesuatu dan melampau

${ }^{34}$ Badr al-Dīn Abū Muḥammad Maḥmūd bin Aḥmad al-'Ayn̄̄, 'Umdah al-Qārī Sharh Șaḥịh al-Bukhārī, ed. 'Abd Allāh Mạ̣mūd Muḥammad 'Umar, (Beirut: Dār al-Kutub al-'Ilmiyyah, 2001), 35:404.

35 Al-‘Aynī, 'Umdah al-Qārī Sharḥ Șaḥịh al-Bukhārī, 35:404. 
terhadapnya sehingga melampaui had (batasan) yang telah ditetapkan dan ia seumpama maksud al-Ta ammuq. ${ }^{36}$ Lalu beliau juga mengaitkan dengan hadith yang dibincangkan ini dan menyatakan bahawa hadith ini mencontohkan perbuatan melontar jamrah oleh Nabi SAW. Jadi, dapat difahami daripada hadith, Nabi SAW telah meminta agar Ibn 'Abbās mengutip batu-batu yang kecil bagi tujuan untuk melaksanakan rukun melontar jamrah. Disebutkan dengan batu yang kecil itu sesuai dengan keadaan sebahagian daripada umat Islam yang salah faham atau melampaui dalam melaksanakan tuntutan itu lalu mereka menggunakan batu-batu yang besar sebagai contohnya sehingga membebankan diri mereka sendiri atau menyusahkan diri sendiri.

\section{Kedua: Larangan Mengada-adakan Sesuatu Baharu Berkaitan Agama}

Mengada-adakan sesuatu yang tidak disyariatkan atau tidak pernah dilakukan oleh Nabi SAW sebagai pembawa syariat khususnya dalam soal agama (ibadah) adalah sesuatu tindakan yang sangat dilarang. Bahkan, tindakan tersebut termasuk dalam perbuatan yang ditolak dan kemungkinan besar amalan atau ibadah tersebut tidak mendapat sebarang pahala di sisi Allah dan jauh daripada penerimaanNya. Daripada Umm al-Mu'minīn 'Āishah RA berkata, Rasulullah SAW bersabda:

$$
\text { مَنْ أَحْحَثَ فِي أَمْرِنَا هَذَا مَا لَيْنَ مِنْهُ فَهُوَ رَدُّ. }
$$

Terjemahan: "Sesiapa yang mengada-adakan suatu perkara di dalam urusan [agama] kami ini yang bukan berasal darinya, maka ia pasti tertolak." 37

36 Aḥmad bin 'Alī bin Ḥajar al-'Asqalānī, Fath al-Bārī Sharḥ Șaḥịh al-Bukhārī, (Beirut: Dār al-Ma'rifah, 1957), 13:278.

37 Hadith riwayat al-Bukhārī, Kitāb al-Ṣilh, Bab Idhā Ișțalaḥu alā șulh al-jawrī fa al-Ṣulḥ Mardūd, no.hadith 2697; Șaḥ̄ḥ Muslim, Kitāb al-'Aqdiyah, Bab Naqd al-Aḥkām al-Bāṭilah waruddu al-Muhaddathāt al-Umūr, no.hadith 4492; Sunan Ibn Mājah, Kitāb al-Sunnah, Bab Ta'zịm Ḥadīth Rasul Allāh SAW wa al-Taghliz 'alā min 'Ariduh, no.hadith 3864; Sunan Abū Dāwūd, Kitāb alSunnah, Bab fì Luzum al-Sunnah, no.hadith 14. Lihat Abū 'Abd Allāh Muhammad bin Ismā‘̄ill al-Bukhārī, al-Jāmi ‘ al-Ṣaḥ̄h al-Bukhārī, ed. Muhīb al-Dīn al-Khātib (Kaherah: Matba'ah al-Salāfiyah, 2000) 267; Muslim bin alḤajjāj Abū Ḥusayn al-Qushayrī al-Naysabūrī, "Șaḥị̣ Muslim," 982. Ibn Mājah, "Sunan Ibn Mājah", 2475 dan Abū Dāwūd, "Sunan Abū Dāwūd," 1561. 
Dalam hadith, kalimah radd bermaksud tertolak atau tidak sah. Manakala ungkapan mā lays minhu, iaitu bukan dari urusan kami bermaksud sesuatu yang bukan dari hukum asalnya. Jadi, hadith ini menyatakan tentang larangan tegas kepada sesiapa yang mengada-adakan sesuatu yang baharu dalam urusan agama atau melakukan sesuatu yang tidak dituntut dalam Islam. ${ }^{38}$ Sekiranya amalan yang dilakukan tidak bertepatan dengan apa yang dibawa oleh Nabi SAW, maka ianya akan terus tertolak dan tidak diterima walaupun amalan yang dilakukan itu berniat ikhlas. Hal ini kerana antara syarat untuk amalan itu diterima adalah salah satunya amalan itu mestilah tidak berlebih-lebih dan mengikut apa yang dituntut oleh Rasulullah SAW. Maksudnya di sini, perbuatan yang dilakukan itu dinilai sebagai ibadah tetapi ianya tidak bersumberkan ajaran Islam atau tidak juga memiliki landasan yang jelas dan lebih dikenali dalam agama dengan istilah bidaah. ${ }^{39}$ Manakala menurut pendapat al-Shāțibī dalam menerangkan maksud perbuatan bidaah ini adalah sesuatu cara atau tindakan beragama yang diada-adakan dengan menyerupai syari'at. Hal itu dilakukan oleh golongan tersebut dengan bertujuan untuk melebihlebihkan dalam beribadah kepada Allah SWT. ${ }^{40}$ Sesetengah pendapat, ada mengatakan bahawa seseorang itu juga boleh dianggap sebagai pelaku bidaah apabila mengharamkan hal-hal yang halal (mubah) iaitu dibolehkan ataupun beribadah kepada Allah SWT dengan amal ibadah yang tidak diajarkan dalam syari'at Islam.

Dapat diketahui dari hadith ini, semua bentuk amalan dan perbuatan yang tidak bersandarkan kepada dalil nas yang jelas adalah tidak diterima serta tertolak. Agama Islam merupakan agama yang sempurna dan tidak ada kurang dan lebihnya. Oleh itu, agama Islam bukannya agama yang berdasarkan ibtid $\bar{a}$ ' iaitu mengada-adakan sesuatu tanpa dalil dan Rasulullah SAW sendiri telah menyebutkan supaya umat Islam tidak melakukan sikap berlebih-lebihan dan mengada-adakan. ${ }^{41}$

\footnotetext{
38 Muhyiddin Yahya bin Sharaf Nawawi, Hadith Arba'in Nawawiyah, terj Abdullah Haidhir (Indonesia: Maktab Dakwah dan Bimbingan Jaliyat Rabwah, 2007), 22.

39 Al-Nawāwī, Hadith Arba'in Nawawiyah, 22.

40 Al-Nawāwī, Hadith Arba'in Nawawiyah, 22.

${ }^{41}$ Nawawi, Hadith Arba in Nawawiyah, 23.
} 
Hadith ini dapat dikaitkan dengan satu hadith sahih, iaitu Ibn Abi Awfa telah berkata:

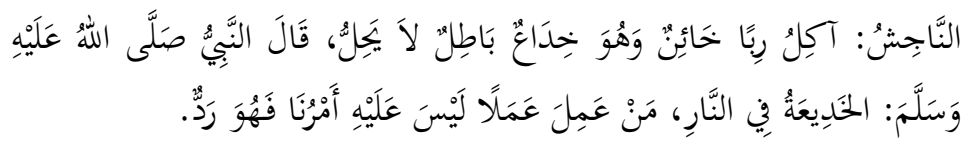

Terjemahan: Al-Näjish adalah pemakan riba dan pengkhianat. Ia merupakan tipu muslihat yang batil dan sama sekali tidak dihalalkan. Nabi SAW bersabda: "Orang yang melakukan penipuan berada di neraka; dan sesiapa yang mengerjakan sesuatu amalan yang bukan termasuk urusan kami, maka ia tertolak." ${ }^{42}$

Perkataan Nājish menurut bahasa adalah mengusik buruan serta membuatnya meninggalkan tempatnya untuk diburu. Manakala dalam syariah bermaksud penambahan harga suatu barang dari orang yang tidak bermaksud membelinya untuk menipu orang lain agar membelinya. ${ }^{43}$ Jadi, dalam hadith ini Nabi SAW menunjukkan satu contoh perbuatan menipu atau mengadaadakan sesuatu yang berkait dengan urusan jual beli yang melibatkan transaksi riba.

\section{Ketiga: Agama Islam itu Mudah dan tidak Memberatkan atau Membebankan.}

Agama Islam adalah agama yang mudah dan tidak membebankan umatnya. Dalam hadith daripada Abū Hurayrah RA daripada Nabi SAW bersabda:

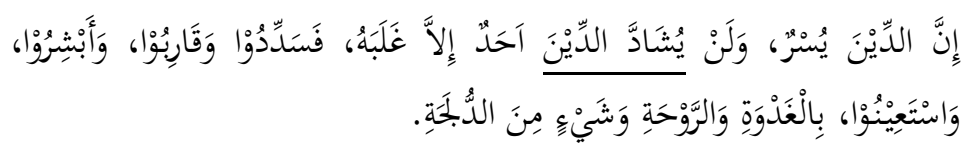

Terjemahan: "Sesungguhnya agama (Islam) itu mudah. Tidaklah seseorang mempersulit (berlebih-lebihan) dalam agama melainkan ia akan dikalahkan. Oleh itu, kerjakanlah dengan semestinya, atau mendekati semestinya dan

\footnotetext{
${ }^{42}$ Hadith riwayat al-Bukhārī, Kitāb al-Buyu', Bāb al-Najash, wa Man Qāla: "La Yajūz Dhālik al-Bay", no. hadith 2134. Lihat Al-Bukhārī, "Ṣaḥị̣̄ al-Bukhārı̄”, dalam Mawsū'at al-Hadìth al-Sharīf, 167.

${ }^{43}$ Ibn Hajar al-'Asqalānī, Fath al-Bārī̄, 12:211.
} 
bergembiralah (dengan pahala Allah) dan mohonlah pertolongan di waktu pagi, petang dan sebahagian malam"44

Dalam hadith, ungkapan Inn al-Dìn yusr atau "Sesungguhnya agama itu mudah" membawa maksud ciri-ciri agama Islam adalah sebagai agama yang diturunkan kepada umat manusia yang terakhir dalam bentuk yang sempurna , agama Islam adalah agama yang telah diredhai oleh Allah SWT. Kemudian, kalimah al-Ghadwah bermaksud permulaan waktu tengahari, dan al-Rawhah pula bermaksud sewaktu terbenamnya matahari, dan al-duljah pula pada waktu akhir malam. Perkataan saddidū bermaksud mengerjakan sesuatu ibadah dengan benar dan tidak berlebihan dan tidak pula menguranginya, qāribu bermaksud, sekiranya ibadah yang dilakukan itu tidak sempurna maka hendaklah mengerjakan yang dekat dengan kesempurnaan, dan juga abshirū bermaksud bahawa bergembiralah kerana akan mendapat balasan pahala atas amal yang dilakukan terus-menerus walaupun sedikit. ${ }^{45}$ Jadi, keseluruhan ungkapan ini merujuk kepada maksud bahawa setiap amalan yang dilakukan, hendaklah disempurnakan dengan baik, bukan dilakukan sehingga membebankan diri sendiri. Bahkan, berusahalah bagi mencapai kesempurnaan kerana dijanjikan balasan pahala di sisi Allah SWT.

Kemudian, istilah mutashaddid iaitu merujuk kepada orang yang berlebihan itu akan dikalahkan juga oleh agamanya, yakni golongan yang suka memberat-beratkan dalam beribadah, pada akhirnya tidak akan terdaya serta merasa jemu untuk melaksanakan tuntutan agama tersebut. ${ }^{46}$ Dalam hal ini, boleh diibaratkan bagi sesiapa yang memberatkan diri sendiri, pada akhirnya nanti akan merasa letih dan penat dalam melaksanakan tuntutan tersebut. Sedangkan diketahui bahawa ciri-ciri agama Islam adalah mudah, sempurna dan tidak membebani diri. Perlakuan berlebih-lebihan itu akan mengundangkan tindakan

${ }^{44}$ Hadith Riwayat al-Bukhārī , Kitāb al-Īman, Bāb al-Dīn Yusrun, no. hadith 39, dan Kitāb al-Marị̄, Bāb Tamanni al-Marị̣ al-Mawta, no. hadith 5673. Rujuk al-Bukhārī, "Șaḥị̣ al-Bukhārī", dalam Mawsū'at al-Hadīth al-Sharīf, 5 dan 486.

45 Muhammad bin Ismā‘n̄l Abū 'Abd Allāh al-Bukhārī, al-Jāmi' al-Ṣahīh alMukhtașar (Ṣahīh al-Bukhārī), ed. Muștafā Dīb al-Bughā (Beirut: Dār Ibn Kathīr, 1987), 5:2147 dan Ibn Hajar al-Asqalani, Fathul Bari: Penjelasan Kitab Shahih al-Bukhari, 1:169.

${ }^{46}$ Al-Asqalani, Fathul Bari: Penjelasan Kitab Shahih al-Bukhari, 1:169. 
yang lebih negatif atau menimbulkan perasaan jemu dan bosan dalam diri individu tersebut. Justeru, Nabi SAW telah menyuruh agar umat baginda melakukan ibadah pada masa dan waktu yang ditentukan iaitu waktu pada pagi, petang dan malam sesuai dengan kemampuan manusia itu sendiri

Jadi, dalam hadith di atas jelas menunjukkan bahawa baginda SAW melarang memiliki sikap ghuluw atau tanațtu" atau tashaddud, kerana ianya bukan sahaja boleh membinasakan diri yang melakukannya, tetapi juga boleh merosak imej Islam. Tambahan lagi, diketahui bahawa Nabi SAW diutuskan sebagai "pemudah cara" bukan membebani umat baginda.

Rasulullah SAW pernah bersabda di dalam hadithnya yang bermaksud: "Sesungguhnya Allah SWT tidak mengutusku untuk mempersulit atau memperberat, melainkan sebagai seorang pengajar yang memudahkan." ${ }^{47}$ Secara dasarnya, agama Islam yang diturunkan oleh Allah SWT adalah mudah kerana Allah mengetahui kemampuan yang ada pada manusia seperti firmanNya dalam surah al-Baqarah ayat 286 yang bermaksud: "Allah tidak membebani seseorang melainkan sesuai dengan kesanggupannya"; dan firman Allah SWT lagi pada ayat 185 surah al-Baqarah yang bermaksud: "Allah menghendaki kamu beroleh kemudahan dan Ia tidak menghendaki kamu menanggung kesukaran".

Ibn Hajar al-'Asqalānī telah memberikan contoh berkaitan ciri agama Islam yang mudah serta membezakan Islam daripada agama lain yang wujud di dunia ini. Contohnya tentang taubat, di mana umat terdahulu untuk diterima taubatnya, sangat rumit sehinggakan ada dalam kalangan mereka yang diharuskan untuk bunuh diri. Sedangkan bagi kaum Muslimin cukuplah hanya dengan menyesali dosa-dosanya, tetapi seharusnya berjanji tidak mengulangi kesalahan dan kesilapan yang dilakukan dahulu serta memperbanyakkan kebaikan. Menurutnya lagi, hadith ini berkait rapat dengan hadith-hadith sebelumnya iaitu hadith mengenai ibadah solat, puasa, dan jihad adalah sebahagian daripada iman dan merupakan ibadah utama bagi umat Islam. Walau bagaimanapun hadith ini memberi peringatan bahawa dalam

${ }^{47}$ Hadith riwayat Muslim, Kitāb al-Ṭalāq, Bab Bayān an Takhyirah Imra'atah lā Yakuna Tallaqan illā bi al-Niyah, no. hadith 3690. Lihat Muslim bin al-Hajjāj Abū Ḥusayn al-Qushayrī al-Naysabūrī, "Șahīḥ Muslim,” 929. 
melaksanakan ibadah-ibadah tersebut haruslah bersesuaian dengan ciri-ciri agama Islam yang mudah dengan tidak membebankan diri dan terlampau ekstrem (berlebih-lebih). ${ }^{48}$

Demikian juga Badr al-Dīn al-'Ayn̄̄ menyebutkan bahawa maksud "Agama (Islam) itu mudah" iaitu dari aspek puasa Ramadan di mana diharuskan untuk melewatkannya (atau menggantikannya) pada masa yang lain disebabkan oleh musafir atau sakit yang berbeza dengan solat (yang tidak boleh berbuat demikian). Demikian juga boleh meninggalkan puasa itu bagi orang yang sangat tua, yang memadai dengan membayar fidyah sahaja (sebagai ganti puasa itu) tetapi tidak pada solat. Bahkan, puasa itu hanya dilaksanakan hanya sebulan dalam tempoh setahun (12 bulan) sedangkan puasa perlu dilakukan setiap hari siang dan malam lima waktu. ${ }^{49}$

Kemudian, agama Islam itu mudah juga boleh dinisbahkan kepada zatnya iaitu perihal agama Islam itu sendiri dan perbandingan dengan agama-agama yang lain. Zahirnya, Allah SWT telah mengangkat segala kepayahan kepada umat-umat seperti tidak harus solat di masjid, tidak boleh bersuci dengan debu tanah, tidak boleh memotong pakaian yang terkena najis dan diterima taubat dengan membunuh diri dan sebagainya. Dengan kelembutan dan rahmat Allah, diangkatkan semua itu daripada umat Nabi SAW sesuai dengan firman Allah SWT ada ayat 87 surah al-Hajj:

$$
\text { وَمَا بحَعلَ عَلَيْكُمْ فِي الدِّينِ مِنْ حَرَجِ. }
$$

Terjemahan: "Dia (Allah) tidak menjadikan kamu menanggung sesuatu keberatan dan susah payah dalam perkara agama." 50

Ibn Bațāal menyatakan bahawa yang dimaksudkan dengan alDìn merujuk kepada al-A'māl (segala pekerjaan atau amalan) kerana itu dikatakan al-Dìn yusr (agama itu mudah). Kemudian, segala kemudahan itu telah diterangkan dalam hadith (di atas) "kerjakanlah keseluruhannya daripada segala amalan perbuatan". Sedangkan al-Yusr itu merujuk kepada maksud al-Lin (lembut)

\footnotetext{
48 Al-'Asqalānī, Fatḥ al-Bārī Sharḥ Șah̄ịh al-Bukhārī, 1:93. Rujuk juga Ibn Hajar al-Asqalani, Fathul Bari: Penjelasan Kitab Shahih al-Bukhari, 1:170

49 Badr al-Dīn al-'Aynī, 'Umdah al-Qārī, 2: 126-127.

50 Al-'Aynī, 'Umdah al-Qārī, 2:127
} 
dan al-Inqiyād (mudah diuruskan atau dilaksanakan). Manakala al-Dìn yang disifatkan dengan sifat mudah dan payah itu adalah merujuk kepada segala amal perbuatan. ${ }^{51}$

Merujuk kepada hadith-hadith tersebut dapat diringkaskan pemahaman berkaitan dengan ekstrem dalam kerangka hadith adalah seperti dalam jadual berikut:

Jadual 3.0: Skop Makna dari Sudut Pemahaman

Terhadap Istilah Ekstrem dalam al-Kutub al-Sittah

\begin{tabular}{|c|c|c|}
\hline Tema & $\begin{array}{c}\text { Tema dalam } \\
\text { Hadith Berkaitan } \\
\text { dengan Ekstrem }\end{array}$ & $\begin{array}{l}\text { Aspek Perbincangan Hadith dan Batasan } \\
\text { Makna dari Sudut Ekstrem }\end{array}$ \\
\hline I & $\begin{array}{l}\text { Larangan } \\
\text { Melampaui Batas, } \\
\text { Ekstrem atau } \\
\text { Memberatkan } \\
\text { Sesuatu }\end{array}$ & $\begin{array}{l}\text { Perbincangan terhadap tiga hadith yang } \\
\text { menyebutkan tentang larangan yang jelas } \\
\text { daripada sikap ekstrem iaitu merujuk } \\
\text { kepada kecelakaan bagi orang yang } \\
\text { melampaui batas (al-Munați } \bar{u} n \text { ); } \\
\text { larangan membebani diri (al-Takalluf) } \\
\text { dan larangan berlebih-lebihan dalam } \\
\text { agama (al-Ghuluw). Makna dalam ketiga- } \\
\text { tiga hadith ini jelas bersifat teori umum } \\
\text { berkaitan dengan ekstrem dan merujuk } \\
\text { kepada skop yang berbeza dan } \\
\text { membicarakan bentuk-bentuk atau ciri- } \\
\text { ciri yang melambangkan kepada ekstrem } \\
\text { atau sikap ekstrem itu. }\end{array}$ \\
\hline VIII & $\begin{array}{l}\text { Larangan } \\
\text { Mengada-adakan } \\
\text { Sesuatu Baharu } \\
\text { Berkaitan Agama }\end{array}$ & $\begin{array}{l}\text { Perbincangan berkaitan dengan tindakan } \\
\text { mengadakan sesuatu yang tidak ada } \\
\text { dalam agama khusus berkaitan dengan } \\
\text { ibadah bermakna bahawa telah } \\
\text { melampaui atau berlebih-lebih dalam } \\
\text { agama }\end{array}$ \\
\hline IX & $\begin{array}{l}\text { Agama Tidak } \\
\text { Memberatkan/ } \\
\text { Membebankan }\end{array}$ & $\begin{array}{l}\text { Perbincangan berkaitan dengan tindakan } \\
\text { atau sikap yang suka membebani diri atau } \\
\text { memberatkan diri dengan sesuatu yang } \\
\text { tidak diajar dalam agama dianggap } \\
\text { sebagai tindakan ekstrem dalam } \\
\text { beragama. Sebenarnya Islam agama yang } \\
\text { memudahkan bukan memayahkan. }\end{array}$ \\
\hline
\end{tabular}

51 Al-'Aynī, 'Umdah al-Qārī, 2:127 


\section{Penutup}

Berdasarkan kepada perbincangan berkaitan dengan ekstrem dengan rujukan kepada nas al-Quran dan hadith serta penjelasan daripada para pentafsir dan pensyarah hadith dapat disimpulkan bahawa terdapat beberapa istilah yang dapat menjelaskan tentang ekstrem sama ada bersifat umum pemahaman daripada nas atau bersifat secara khusus. Daripada rujukan nas al-Quran dan hadith, terdapat beberapa ungkapan seperti al-takalluf, al-tanațtu', almu'tadīn, al-ghuluw, al-tashdìd dan sebagai. Keseluruhan apa yang difahami dan digambarkan dalam al-Quran dan hadith menggambarkan kepada keadaan di mana sikap atau tindakan seseorang yang ekstrem yakni melampau sehingga berlebihlebihan dalam melakukan sesuatu ibadah, sikap memberatberatkan diri dalam sesuatu perbuatan serta sikap melampaui batas dan had yang ditetapkan. Dalam hadith didapati juga bahawa tindakan mengada-adakan sesuatu yang baharu dalam soal berkaitan dengan agama adalah juga termasuk dalam sikap ekstrem. Dalam pada itu, sifat agama yang memudahkan dan tidak memayahkan atau membebankan penganut jelas menunjukkan bahawa Islam melalui pemahaman terhadap nas al-Quran dan hadith Nabi SAW, jelas melarang perbuatan atau sikap ekstrem tersebut.

\section{Penghargaan:}

Artikel ini hasil daripada penyelidikan di bawah geran penyelidikan University Malaya Research Grantt (UMRG) bernombor RG482-15HNE bertajuk: "Menangani Budaya Pemikiran Ekstrem Agama dalam Kalangan Belia: Ke Arah Penyelesaian Melalui Kerangka Al-Quran dan Al-Sunnah."

\section{Rujukan}

Achmad Mubarok MA. "Fanatik dan Toleransi", laman sesawang Mubarak Institute, dicapai 25 Julai 2016, http://mubarokinstitute.blogspot.my/2010/12/fanatik-dan-toleransi-oleh-profdr.html.

Al-'Ayn̄̄, Badr al-Dīn Abū Muḥammad Mạ̣mūd bin Aḥmad. 'Umdah al-Qārī Sharh Sahịh al-Bukhārī, ed. 'Abd Allāh Maḥmūd Muhammad 'Umar. Beirut: Dār al-Kutub al'Ilmiyyah, 2001. 
Al-Bukhārī, Abū 'Abd Allāh Muḥammad bin Ismā‘̄il. Al-Jāmi ‘ alSahīh al-Bukhārī, ed. Muhīb al-Dīn al-Khātib. Kaherah: Matba'ah al-Salāfiyah, 2000.

Al-Bukhārī, Muḥammad bin Ismā'īl Abū 'Abd Allāh. Al-Jāmi' alSahịhh al-Mukhtașar (Ṣahīh al-Bukhārī), ed. Mușțafā Dīb alBughā. Beirut: Dār Ibn Kathīr, 1987.

Dewan Bahasa dan Pustaka, "ekstreme", laman sesawang Pusat Rujukan Persuratan Melayu, dicapai 4 Febuari 2016, http://prpm.dbp.gov.my/Search.aspx?k=ekstreme

Dinda Ayu Kusumaningtyas. "Fanatisme dan Radikalisme Agama". Latihan Ilmiah di Jurusan Sistem Informasi, Sekolah Tinggi Manajemen Informatika dan Komputer, AMIKOM, Yogyakarta, 2011.

Ibn Hajar al-'Asqalānī, Aḥmad bin 'Alī. Fath al-Bārī Sharḥ Șah̄̄h al-Bukhārī. Beirut: Dār al-Ma'rifah, 1957.

Ibn Hajar al-Asqalani. Fathul Bari: Penjelasan Kitab Shahih alBukhari, terj Amir al-Din, ed. Abu Rania. Jakarta: Pustaka Azzam, 2011.

Ibn Manẓūr, Muḥammad ibn Mukarram ibn 'Alī ibn Aḥmad. Lisān al-'Arab (Kaherah: Dār al-Ma'ārif), 9:113.

Mansor Mohd Noor. "Memahami dan Mengurus Ekstremeisme Agama di Malaysia", Journal of Ethics, Legal and Govermance 1 (2005), 53.

Marwan Hadidi. S.PdI, Artikel: Perintah Yang Disesuaikan Dengan Kemampuan. Jakarta: Yayasan Pendidikan Islam alAtsary, 2014.

Mawsū'at al-Hadīth al-Sharīf: al-Kutub al-Sittah, ed. Șalih bin 'Abd al- 'Aziz Al al-Shaykh. Riyadh: Dār al-Salām, 2000.

Md Asham bin Ahmad. "Moderation in Islam: A Conseptual Analysis of Wasatiyyah", TAFHIM: IKIM Journal of Islam and the Contemporary World 4, (2011): 29-46, 43.

Mohamad Kamil Hj Ab Majid. "Fanatik dan Taksub dalam Islam: Analisis Pandangan al-Qardawi”, Jurnal Usuluddin 18, (2003), 27.

Mohd Roslan Mohd Nor. Kefahaman Islam Semasa di Malaysia: Realiti dan Cabaran (Ekstremisme rentas agama dan tamadun). Selangor: Persatuan Ulama' Malaysia, 2015. 
Muhammad Yusuf al-Qaradawi. Kebangunan Islam di Antara Tentangan dan Ekstrimisme, terj. Muhammad Rivai Batubara. Kuala Lumpur: Angkatan Belia Islam Malaysia, 1984.

Muhyiddin Yahya bin Sharaf Nawawi. Hadith Arba in Nawawiyah, terj Abdullah Haidhir. Indonesia: Maktab Dakwah dan Bimbingan Jaliyat Rabwah, 2007.

PKPIM UNISEL, "Pengertian Ekstremisme," laman sesawang PKPIM UNISEL, dicapai pada 22 November 2015, http://uniselpkpim.blogspot.my/2009/09/pengertianekstremisme.html?m=1.

Santayana, George. Life of Reason: Reason in Common Sense. New York: Charles Scribner's Sons, 1905.

Shams al-Haq, Abī Ṭayyib Muḥammad. Awn al-Ma'būd Sharh Sunan Abī Dāwūd, ed. 'Abd al-Raḥman Muḥammad 'Uthmān. Madinah: Maktabah al-Salāfiyah,1968.

Syāhīn Lashīn, Mūsā. Fath al-Mu'ìn Sharh Sahī̄h Muslim. Kaherah: Dār al-Syuruq, 2002. 